PUTTING FAMILIES FIRST

PREVENTION AND CHILD CARE 


\author{
Also by Bob Holman \\ Trading in Children \\ Poverty: Explanations of Social Deprivation \\ Kids at the Door \\ Resourceful Friends
}




\title{
PUTTING FAMILIES FIRST
}

\author{
Prevention and Child Care \\ A study of prevention by statutory and \\ voluntary agencies
}

BOB HOLMAN

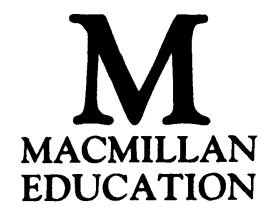


(C) Bob Holman 1988

All rights reserved. No reproduction, copy or transmission of this publication may be made without written permission.

No paragraph of this publication may be reproduced, copied or transmitted save with written permission or in accordance with the provisions of the Copyright Act 1956 (as amended), or under the terms of any licence permitting limited copying issued by the Copyright Licensing Agency, 33-4 Alfred Place, London WC1E 7DP.

Any person who does any unauthorised act in relation to this publication may be liable to criminal prosecution and civil claims for damages.

First published 1988

Published by

MACMILLAN EDUCATION LTD

Houndmills, Basingstoke, Hampshire RG21 2XS

and London

Companies and representatives

throughout the world

British Library Cataloguing in Publication Data

Holman, Bob

Putting families first: prevention and child care: a study of prevention by

statutory and voluntary agencies.

1. Child welfare - Great Britain

I. Title

362.7'32'0941 HV751.A6

ISBN 978-0-333-43794-0

ISBN 978-1-349-19057-7 (eBook)

DOI 10.1007/978-1-349-19057-7 
To the memory of Donald Bowie

deputy director and director of the Church of England Children's Society 1964 to 1982. 


\section{Contents}

Preface $\quad$ ix

1. The Victorian Legacy 1

Nineteenth-century conditions 2

The Poor Law's care of children 3

The voluntary contribution- 'The saving of the children' 5

No place for prevention $\quad 8$

The legacy 14

Children of the state, 1900-39

Explanations $\quad 19$

The voluntary contribution, interwar years 20

Signs of new directions?

Grounds for change $\quad 25$

2. The Children's Departments and Prevention 28

The impact of the Second World War 28

The Curtis and Clyde Reports $\quad 30$

The Children Act 1948

Other reforms 36

The case for prevention $\quad 37$

The legislation of 1963 and $1969 \quad 41$

Prevention undertaken, 1963-71 45

The voluntary societies $\quad 48$

The meaning of prevention $\quad 51$

Prevention established $\quad 53$

3. Problems for Prevention 55

Reorganisation and prevention $\quad 55$

Parenting and prevention $\quad 59$

Poverty and prevention $\quad 61$

Permanency and prevention $\quad 66$

$\begin{array}{ll}\text { The voluntary contribution } & 75\end{array}$

$\begin{array}{ll}\text { The meaning of prevention } & 80\end{array}$ 
4. Prevention at Present

For prevention

Against prevention

Social work: negative and positive

The response of the SSDs

The voluntary organisations

The meaning of prevention

Key features

5. The Voluntary Projects

Baron's Close Young Family Centre

The Gerard Avenue Project (GAP)

The Roundhill Project

The Walcot Centre

The other projects

Three models

6. The Voluntary Contribution 168

Does it work? 168

The essential framework $\quad 171$

Facilitating prevention $\quad 175$

The voluntary factor $\quad 186$

7. The Pursuit of Prevention 197

The case for prevention $\quad 197$

A strategy for prevention 208

The preventative neighbourhood 221

References 225

Index 243 


\section{Preface}

I have spent my working life as a child-care officer with a local authority, as an academic, and as a member of a community project belonging to a voluntary society. In all these occupations preventing children from being unnecessarily removed from their natural parents and preventing them from having to endure social disadvantages within their families have been major concerns of my life. I am therefore grateful that my former employers, the Children's Society, allowed me the time and facilities to make a study of prevention in child care. Its director, Ian Sparks, gave me much encouragement both to start and complete the task.

My thanks are due to a number of colleagues and friends who took the time and effort to read and make suggestions about parts of the book. In particular, I make mention of Winifred Stone, Mary Joynson, Jane Rowe, Robin Chapman, Jo Tunnard and Jo Campling. The study entailed visiting and staying at over twenty voluntary and statutory projects and centres and within them interviewing many staff, volunteers and local residents. I am grateful to them all for their patience and kindness. I am especially indebted to Audrey Browne, who typed much of this book and who, for nearly a decade, put up with my idiosyncrasies. Lastly, as ever, my thanks go to Annette, Ruth and David for their continuing interest and support.

In writing this study I received great help from three child-care studies, which I read in draft forms. They have now been published and I take this opportunity to list them: J. Packman with J. Randall and N. Jacques, Who Needs Care?, Blackwell, 1986; M. Fisher, P. Marsh, D. Phillips with E. Sainsbury, In and out of Care, Batsford, 1986; and S. Millham, R. Bullock, K. Hosie and M. Haak, Lost In Care, Gower, 1986.

Also, since the chapters were completed, the government has published a white paper, The Law on Child Care and Family Services (HMSO, 1987) in which it accepts that the state should be ready to help parents to bring up their children and to lessen the 
risk of family breakdown. It then proposes legislation based on some of the recommendations of the Review of Child Care Law (HMSO, 1985). If enacted, the legislation would facilitate prevention in child care, though the government does not give a date by which it will make resources available to local authorities to implement such new responsibilities.

This book is published in conjunction with the Children's Society, which is a firm advocate of prevention. However, I wish to make it clear that the views expressed in the book and any errors made are attributable to the author. My hope is that this volume will stimulate more extensive and more effective practice of prevention in child care.

Glasgow

BOB HOLMAN 